days to two weeks earlier than normal. In the fall migrations single birds were seen in three different areas, two of which could have been the same bird. The best record was from Richard where a pair with one young was seen on October 7. During the summer aerial surveys on the nesting ground, only two young were seen. It's too early to say what the winter count will be, but it doesn't look encouraging as the average annual loss seems to be close to four birds.

The New Orleans captive bird laid seven eggs, but reared no young. Here again we are wasting valuable time by not managing the present flock. There have been so many successful avicultural programmes that we believe someone with the necessary "know-how" should be asked to advise on a whooping crane programme. At present the whole whooping crane programme consists in tracking their movements and encouraging safe passage along the flyway. Without authority and support, we can only wait and see whether the cranes escape the heavy toll twice before taken of their numbers.

PARKS A N D WILDERNESS AREAS-It is encouraging to see the province setting up new areas for recreational use. Every individual landowner, too, should be urged to help preserve wilderness areas for recreational use and for study (at both popular and scientific levels). The conservation committee does not function for itself but rather to encourage everyone to participate in conservation. We should like all interested people to keep us informed of projects or continuing programmes as well as individual efforts. When this information is made public others are encouraged to give similar support.

\title{
Red Crossbills Feeding on Aphids
}

\section{By G. F. Ledingham, Regina}

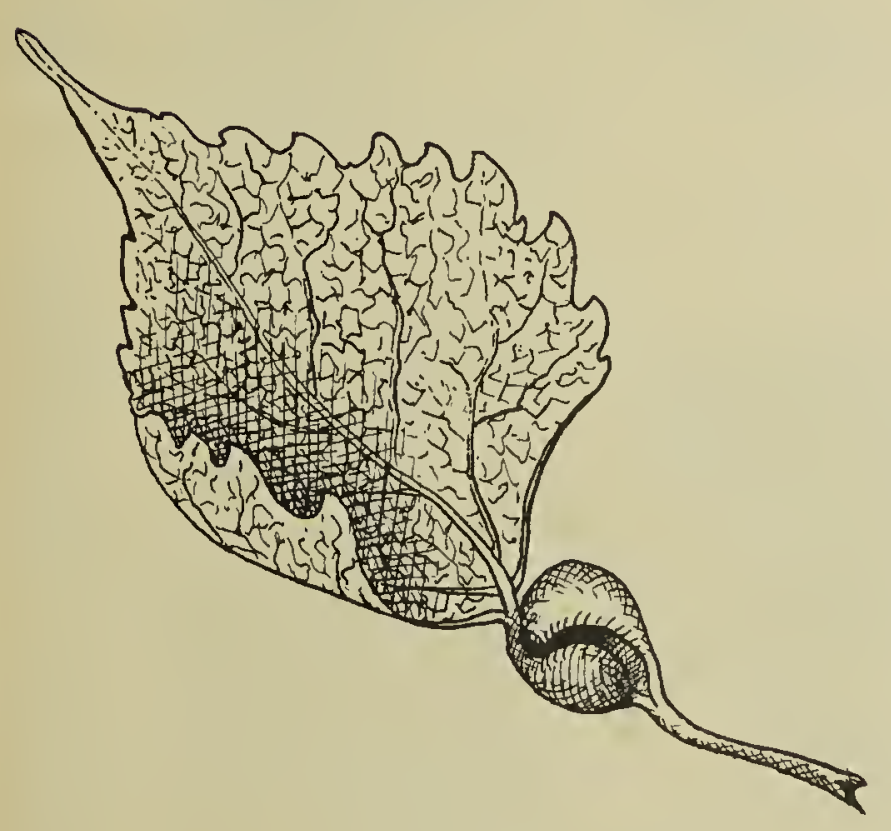

Sketch by L. Ostoforoft

On July 29, 1959, I stopped at noon under three old eastern cottonwoods (Populus deltoides Bartr. ex Marsh.) which grow in front of our house in Regina. Tr.ere was a familiar but.unexpected chattering of birds above me. Soon I saw a male Red Crossbill (Loxia curvirostra) in full plumage. My wife, Betty Cruickshank and Arthur Taylor soon joined me and we saw about ten crossbills in various plumages.

The interesting thing to me was first that they were here in Regina in July, second that they were in poplar trees. I had never trought of the crossbill as feeding on anything but the seeds of conifers. These crossbills were contentedly feeding in poplars in July. I watched the male snip into a leaf gall, obviously feeding on the insects within the gall, and then go on to the next gall. All the birds were feeding in the same way. Sometimes the leaf would break off at the gall and come floating down. A couple of hours later there were over 200 of these leaves on the ground and the crossbills had moved on and were not seen feeding here again.

Mr. Lloyd O. T. Peterson, entomologist at the Research Branch, Canada Department of Agriculture, Forest Nursery Station, Indian Head, kindly identified the insect for me as the poplar aphid, Pemphigui populicaulis Fitch. "Its galls are subglobular. They always occur at the base of the cottonwood leaf and the opening in the gall is oblique. No 
doubt this aphid ras a complicated life cycle involving a secondary host. Its presence on cottonwood is well known but the damage to the host trees is not considered extensive or serious; consequently, detailed efforts to study its life history in our region for the purpose of formulating control measures have not been undertaken."

P. A. Taverner in his Birds of
Western Canada, 1926, says that Red Crossbills "seem specially fond of the little woolly aphis. It was very interesting to watch a captive specimen open galls on poplar leaves. Seizing the fleshy tissue with the bill tips so that the points crossed within the mass, it gave a little twist of the head that split the gall wide open and the aphids within were removed with the tongue."

\section{Golden Eagles Preying on Porcupines}

\section{By Lawrence Ostoforoff, Sask. Museum of Nat. History}

Arthur C. Bent, in Life Histories of North American Birds of Prey, Part I, 1937, page 304, lists the porcupine as a food item of the Golden Eagle (Aquila chrysaëtos). On page 306 Bent gives the following example: "This bold bird sometimes 'catches a 'Tartar.' Albert Lano (1922) had one brought to rim that had attacked a porcupine; 'it was literally covered underneath with quills. In fact there were a number of quills in the roof of its mouth. The body was much emaciated and many of the quills had penetrated deep into the flesh causing pus to form'."

Among Golden Eagle specimens examined by museum staff in recent years, three specimens showed contact with porcupines. One immature female Golden Eagle shot at Milden, Saskatchewan, December, 1958, had approximately a hundred porcupine quills imbedded in its feet. Its right foot had 62 quills, the left foot 33 quills, most of which were bitten off or torn off close to the flesh. Five quills were deeply imbedded in the roof of the mouth, and the gizzard contained a loose mass of quills, lying parallel and enclosed with soft hair, in somewhat the same manner as a pellet. Six quills were very slightly attached to the gizzard lining; none was imbedded deeply and none was found in other parts of the intestinal tract. The bird was very thin; weight: 6 pounds, 8 ounces.

F. W. Lahrman, while mounting an immature Golden Eagle shot at Bethune, Saskatchewan, November, 1950 , noted some quills lying underneath the leg muscle close to the bone. In addition several quills were

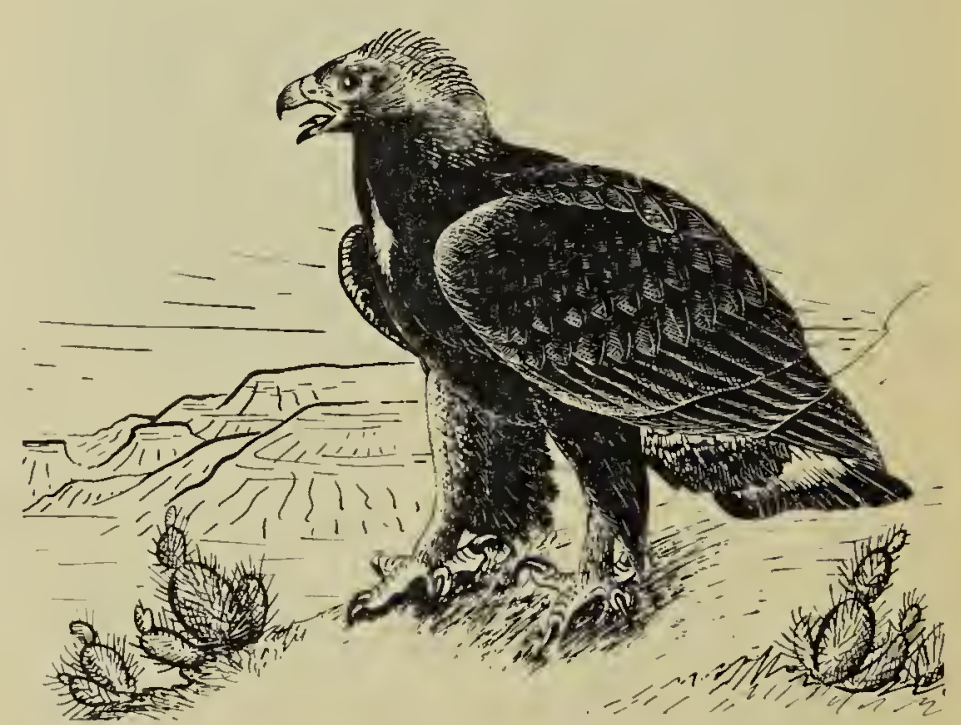

Sketch by $L$. Ostoforoff

found which penetrated the gizzard from the outside. This bird was also very thin.

The third eagle, examined at Mervin, Saskatchewan, by B. C. Shier of the Museum, was so crippled by quills in its feet and mouth that it could no longer hunt its natural prey. It made its way into a chicken coop where it was shot while feeding on a fowl.

Although porcupines are rather common on the Northern Plains, predation by Golden Eagles is probably still a rare occurrence. It is interesting to note that the three Saskatchewan specimens described above were all immature birds, perhaps inexperienced in hunting their usual prey. The dark, slow-moving porcupine on the open prairie-would likely be tempting prey for the young, unwary eagle. 